\title{
History of Secular Tourism in Sinai (1805-1936)
}

\section{Hend Mohamed Abdel Rahman}

\section{"It is to the remarkable scenic charm of these ranges that we hope to call attention"}

\author{
E. N. BUXTON
}

\section{KNIGHTON, 1895}

\begin{abstract}
The issue of the history of secular tourism in Sinai rarely figures out in the writings of historians, though Sinai is well-known as an important destination for religious tourism. European pilgrims to Palestine used to visit religious sites of Sinai, where secular destinations in Sinai were mentioned, described and even praised. Successive rulers and governments in Egypt, from 1805 to 1936, had different attitudes towards Sinai's tourist attractions. Sinai's visitors similarly had different targets of their visits. This paper throws light on the different features of secular tourism in Sinai during the $19^{\text {th }}$ century and early decades of the $20^{\text {th }}$ century of our common era. In Sinai, the visit of religious sites is often mixed with Safari trips and environment enjoyment in a way that produce a unique and unforgettable adventure.
\end{abstract}

Keywords Sinai, hunt, tourism, therapeutic tourism, safari.

\section{Introduction}

Sinai has always been a passageway of different civilizations and cultures over the past millennia. It is often portrayed as a holy ground and a cradle of religions, which played an exceptional role in ancient and modern history. ${ }^{(1)}$ Visiting Moses Mount, St. Catherine Convent, Serbal Mountain, Ayoun Musa, and the ibex-shooting are probably the main attractions of Sinai. During the second half of the $19^{\text {th }}$ century, pilgrims regularly crossed and visited Sinai on their way to Jerusalem. ${ }^{(2)}$ This journey has been taken by the common people and the elite since the Middle Ages. The security procedures imposed by Mohamed Ali family, especially for foreign visitors, on Sinai had attracted more and more visitors, who decided to enjoy Sinai religious and environmental sites. It was only at the beginning of the $20^{\text {th }}$ century that Sinai was placed on the tourism map of Egypt.

Sinai visitors were not only pilgrims, ${ }^{(3)}$ but also explorers and scholars, who visited Sinai with different destinations and targets During the $19^{\text {th }}$ century, a limited number of archaeologists and surveyors went beyond St. Catherine 
Convent to the less-known eastern seaboard. Prominent among the early explorers who visited Sinai are Koller, Rupell Seetzen, Laborde, and Lord Lindsay. Ritter and Robinson are examples of prominent explorers who came to Sinai at a later date. ${ }^{(4)}$ Sinai was also visited by the ibex-shooters and the seekers for recreation and adventures. ${ }^{(0)}$ The features of these secular visits are the focus of this article.

\section{Literature Review}

With rare exceptions, all sources and references to the history of tourism in Sinai lack the description of different features of secular tourism. Travelers and pilgrims' books are an important source for addressing secular tourism in Sinai. Once to Sinai, for instance, is a detailed description for pilgrimage journey during the $15^{\text {th }}$ century. The book has been a fundamental source in confirming that other types of tourism existed and were practiced in Sinai by passing and visiting pilgrims. Although the writings of Farman ${ }^{(6)}$, Stanely, ${ }^{(7)}$ and Browne ${ }^{(8)}$ focus on religious attractions of Sinai, they also shed light on other non-religious tourist destinations in Sinai.

Burckhardt described his secular visit to Sinai under the reign of Mohamed Ali. In his description of Sinai, Wilkinson depended largely on Burckhardt's book. Holland wrote many papers on Sinai, where he gives general description of Sinai attractions in addition to his exploration missions. Lina Eckenstein, who worked with Flinders Petrie in his Sinai expedition of 1905, has presented an influential study on the history of the Sinai peninsula, ${ }^{(9)}$ with a detailed description of Sinai and its people. ${ }^{(10)}$ Major Claude Scudamore Jarvis, who joined the Egyptian Government Service in 1918 and worked as a governor of the Sinai Peninsula from 1923 to 1936 , thewrote numerous books on Sinai. ${ }^{(11)}$ Perhaps his book Yesterday and to-day in Sinai is the most informative monograph with more illustrations. The book of Deborah Manley and Sahar Abdel-Hakim is a brief overview of Sinai and its attractions through the writings of its visitors. The authors mainly cite the visitors' own words to describe Sinai. George Manginis has recently presented a rich study on Mount Sinai: A History of Travellers and Pilgrims. Egyptian Intelligence and Frontier Administration officers endeavour to write Arabic guidebooks for Sinai visitors. Naom Shokeer and Refaat El Gwhary similarly published many books on Sinai. The writings of British officers like Jarvis are a critique of British policies in Sinai. In his Eight Years Wandering in the High Mountains of Sinai Peninsula: A Tale Of two maps, Ahmed Shams provided a full description of Sinai. This monograph is a main source for this article.

It is the aim of this paper to explore the procedures and arrangements to visit Sinai and its development besides other types of activities during 
Sinai's visit by foreigners from 1805 to 1936 . The paper focuses on secular tourism in Sinai from 1805 to 1936. It argues that it is because Mohamed Ali's security procedures in Sinai that many scholars and other foreigners visited Sinai. What can be called scientific tourism flourished in Sinai under the reign of Mohamed Ali, yet it also encouraged other non-academic visitors, who accompanied those scholars. Interest in Sinai as a tourist destination has remarkably increased under Mohamed Ali's reign. It was in 1936 that the Egyptian government and society began to show interest in tourism in Sinai.

\section{Entry procedures}

During the $19^{\text {th }}$ century, there were no definite entry procedures to visit Sinai. The recommendations of the ruler were enough to grant foreign visitors an entry to Sinai and enjoy a safe journey. In 1816, Burckhardt visited Sinai and was granted the two usually required permission: one for visiting the Convent of St. Catherine and the other for Akaba Bay. The ruler's permission to visit Sinai was a guarantee that the deals with the Bedouins would be easier.

In 1882, the British authorities imposed restrict procedures to enter Sinai. In 1906, and following the Turkish attempt to seize Taba, a permission for Sinai entry became fundamental and should be obtained from the Frontiers Administration Headquarters, War Office, Cairo. ${ }^{(12)}$ The permission was not required before 1906, only the Convent introduction letter must be obtained at Cairo or Suez from the Convent's agents. This permission was no longer required after 1936, when certain safety and security procedures should be followed:

1. Convoy of at least two cars or more was allowed to move through Sinai desert, except for visits from Sinai to Palestine through Hassna and Qusaima, where only one car was accepted.

2. All information related to travellers and their vehicles should be recorded at the Kubri (Bridge) police station. ${ }^{(13)}$

\section{The Routes (Fig. 1)}

Until the end of the $19^{\text {th }}$ century, Sinai was regularly visited for the Convent of St. Catherine. Southern parts of Sinai were rarely visited. The outbound and return journey from Cairo to Sinai took up from 15 to 20 days. The discrepancy depended on the length of stay at St. Catherine Convent. ${ }^{(14)}$ Certain routes (Fig. 1), shorter but critical, were taken by those who were under the custody of Egypt's ruler. ${ }^{(15)}$ 


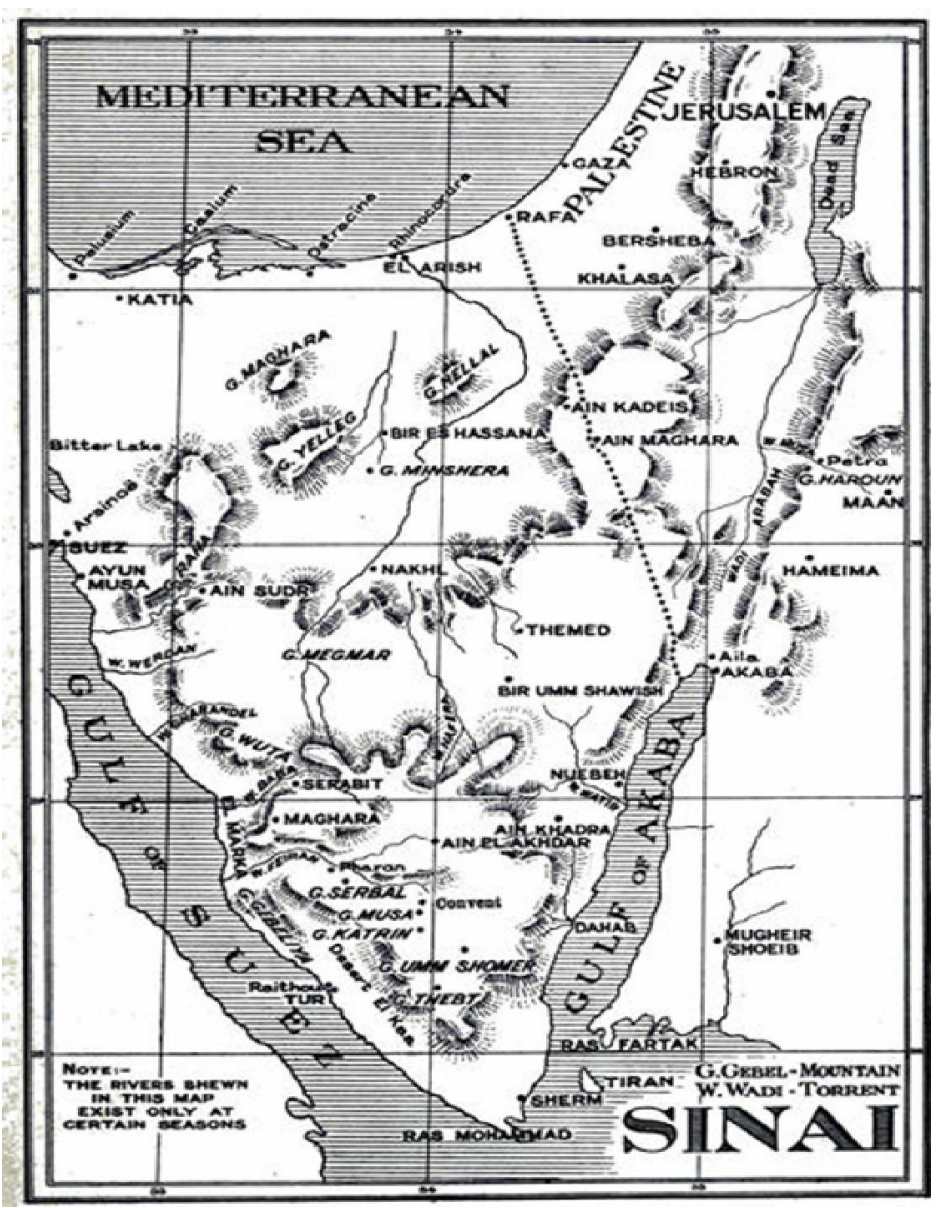

Fig. 1: Map of Sinai with various followed routes (1920)

Source gallica.bnf.fr / Bibliothèque nationale de France

1. From Cairo to Suez: it was expected to take three hours by car.

2. From Suez to Qussaima: the distance was $249 \mathrm{~km}$ and took nearly six hours. $^{(16)}$

1. The first stage to south (Shutt outpost) took one hour to reach Kubri Mitla.

2. From Kubri to "Mitla Pass", the distance was $37 \mathrm{~km}$ and it took about one hour and 20 minutes.

3. Mitla Pass to Sudr Heitan (a name of strange mountain of grae colour striped with white lines) the distance was about $26 \mathrm{~km}$ and was travelled in an hour.

4. Sudr Heitan to Hasana, 2 hours and half.

5. From Hassana to Qussaima, 2 hours and 15 minutes for those who decided to visit Jerusalem. 
6. From Hassana and passing by Gabal el-Halal. Direct travel from Cairo to el-Arish nearly took 11 hours.

1. From Cairo to St. Catherine Convent: the distance is $392 \mathrm{~km}$ and used to take 15 hours.

2. Firstly from Shatt to Ayoun Mousa.

3. Secondly from Ayoun Mousa to Abu Zenima passing by Wadi Sudr (25 km from Ayoun Mousa), where Palmer was assassinated.

4. From Abu Zenima to Wadi Feiran passing by Sarabit el-Khadem and Wadi Maghara (2 hours and 15 minutes).

5. From Wadi Sudr to Wadi Feiran is $24 \mathrm{~km}$.

6. From Wadi Feiran to the Convent of St. Catherin is $52 \mathrm{~km}{ }^{(17)}$

Before the $20^{\text {th }}$ century, the main means of transport in Sinai was camels, which were hired with local guides and workmen from the Bedouin tribe in whose area the travellers would pass. This arrangement continued for a time, but sooner the travellers could hire whatever and whoever they pleased. ${ }^{(18)}$ The visit to Sinai was later developed as result of many global changes in means of transportations from camels to motor vehicles, which made Sinai more accessible to visitors. During this time, there were no paved roads for cars in Sinai. Visitors with motorcars should carry with them a basket of messenger pigeons that would be utilized in case of car's breakdown, but the idea was not successful enough to continue. In 1925, the first road between Arish and Aqaba was paved and this was followed by many roads. It follows that the journey from Cairo to el-Arish only took 11 hours.

In 1926, 5 tourist cars, in average, used to cross Sinai daily. In 1935, traffic increased to be 50 cars daily on Sinai tracks. ${ }^{(19)}$ A new car road was paved from Suez to Tor, hence the journey from Suez to Tor only took 8.5 hours. ${ }^{(20)}$ The new paved car roads werealmost built on the old camel tracks. ${ }^{(21)}$ Using cars in Sinai desert was more economic than travel by train. While the train costs an individual $3 \mathrm{LE}$, the expense of the car journey to Jerusalem through Sinai is only 2 LE. ${ }^{(22)}$ In the 1930s, there was no need for accompanying a dragoman to travel through Sinai's tracks. ${ }^{(23)}$

\section{The Dragoman}

Absence of local guides for any reason used to be critical for travellers through Sinai. ${ }^{(24)}$ For security reasons and his acquaintance with the tracks of Sinai, the dragoman continued has always been an important element in Sinai journeys since the Middle Ages. The local guide in Egypt was called by travellers dragoman, the person responsible in full for the safety and satisfaction of travellers. Some of Sinai dragomen, however, were less responsible and conspired to earn more money from travellers. The more far 
the traveller from the authority, the more expected problems to suffer from dragomen during his journey through Sinai. The dragoman used to offer the interpretation, mediation, and guidance services; he also used to transfer the Bedouin culture to his visitors. Travellers' guidebooks normally list guidelines of dealing with dragomen in hope of avoiding being deceived or looted.

With the turn of the $19^{\text {th }}$ century, Bedouins used to be in Cairo every spring waiting for jobs, as guides for Sinai visitors and renters for camels. Employed men for guarding the travellers and hired camels were included in the contract, which had to be signed at Cairo before the journey starts. Requests of hiring guides and camels could be submitted in advance by mailing the Suez Hotel, though in the rush-top season both guides and camels were sometimes not available in Suez. In this case, a supply from the Sinai desert was saved in 3 or 4 days. Until the $20^{\text {th }}$ century, horses and mules were exchanged for camels at Suez. ${ }^{(25)}$

If the traveller chooses to move from Suez to Tor by sea, which was seen as an extra privilege, Bedouins would normally ask for extra money. ${ }^{(26)}$ Petrie depended on a shipping company, Beytes, in Suez to reach best deals with Bedouins. ${ }^{(27)}$ Except for camels, all the journey supplies, such as tents, food, and etc..., were sent from Cairo to Suez by railway. ${ }^{(28)}$

\section{Environmental Tourism in Sinai}

The outstanding environmental features of Sinai have always imposed itself on all visitors, regardless of their targets and goals. Sinai visitors and passengers were obliged to save time and effort to enjoy the beauty of Sinai's environment. They inked these sits with religious incidents that once happened on Sinai's land, and they mainly came to follow it and check where and what exactly happened. ${ }^{(29)}$ Environmental characteristics of Sinai attracted visitors who came to visit religious sites. In the early $15^{\text {th }}$ century, Felix Fabri commented on the great stony mountains of Sinai as never seen before in all his journeys. The face of the rock was of many colors, yellow, red, black and other colors ...". Another traveler with Felix described the valleys of Sinai as "majestic surroundings". ${ }^{(30)}$. They came not to see Sinai's beauty, but they could not ignore it. Although it was pilgrimage, Felix's company were not going to let slip an opportunity of officially sponsored sea-bathing, rambled along the beach, picked up shells and pieces of white coral and stones pretty enough to be set in rings, crystals, mother-of-pearl shells, shells with strange names-"Venus shell, wild ducks, gudgeons, bulimus, and numberless other like kinds which were a source of joy and surprise. At last, sitting at ease upon the beach they ate and drank happily the usual picnic meal of mid-day". ${ }^{(31)}$ Three hundred years later, Wilkinson 
described the unusual appearance of Mount Moses' rocks,. ${ }^{(32)}$ and he mentioned Ras Mohamed and Tor, an area that, in his view, does not deserve visit. $^{(33)}$

Although Abbas Pasha (1848-1854) ${ }^{(34)}$ is "best remembered for the emancipation of the fellaheen and the construction of the Cairo-Alexandria railway line in 1851", he "had a significant influence on the immediate area around St. Catherine. He ordered the construction of the mountain top palace and commissioned the building of the camel path up to Mount Sinai and the soldiers' barracks on the way to the Convent." ${ }^{(35)}$ The road, starting at Abu Jeefa and going through Wadi Tubug and Wadi Zawatin, is still in use today. ${ }^{(36)}$

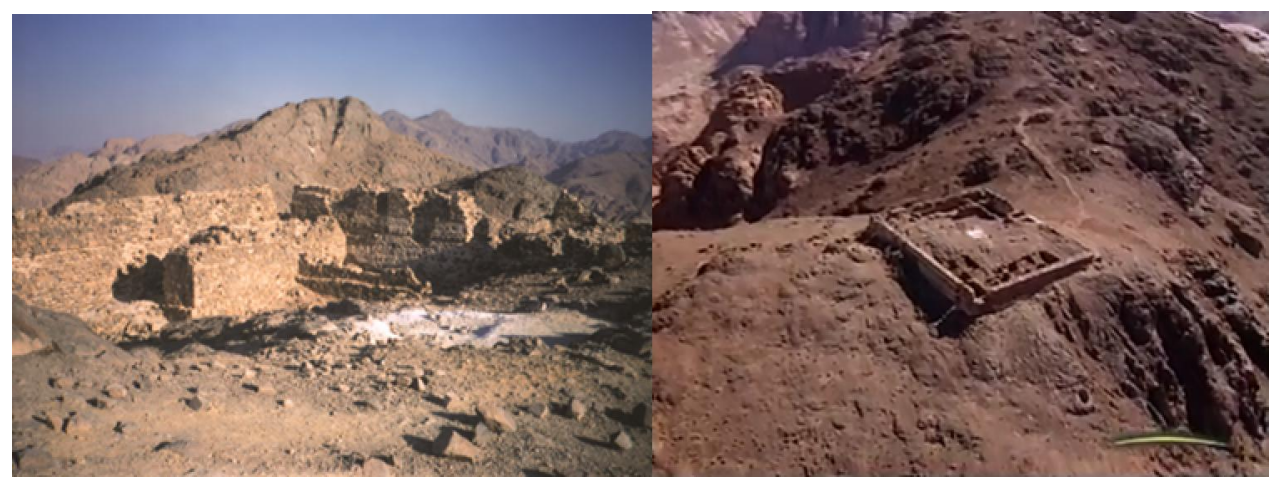

Fig. (2) Jebel Abbas Pasha, where one can explore the palace, which was built on a mountain called at the time Jebel Tinya, but later named after him and today called Jebel Abbas Basha.( Source : Shams, A. August 2011e. Eight Years wandering in the High Mountains of Sinai Peninsula: A Tale of Two Maps, Cairo, Sinai Peninsula Research 2000-2013 CE)

Abbas Pasha has endeavored to find the healthiest spot with the purest atmosphere for his palace in Sinai. In 1857, according to Horatius, Abbas took distributed several legs of mutton in different parts of the desert, the leg remained longest un-decaying was considered the driest and healthiest and there a palace was built. ${ }^{(37)}$ In the same way, a site for another palace was chosen in the Suez desert leading to Sinai,. This was called the white castle, where Abbas used to look after his collection of horses. ${ }^{(38)}$ Sinai's palace was not finished before the death of Abbas, and it was not completed by his follower Said Pasha (Fig. 2).

Comte de Pardieu described the rare natural features of Sinai, even the gazelle chasing. He was admired by Sinai's environment and his words about Sinai were a better call for visiting Sinai than any guidebook. He flattered its quietness and isolation; his words tempted his reader to go through the same experience. ${ }^{(39)}$ Cook's guidebook described the nature of Sinai "as beautiful to see as they are difficult to describe" , each valley had its so own 
characteristics that no one is a copy of another, Cook's praised Sinai's weather as dry and the air is healthy and life-giving. ${ }^{(40)}$

The fall of ice was a strange phenomenon on this hot land, something that was admired by Americans who ascended Jebel Katharin at the end of $19^{\text {th }}$ century. They found ice near the summit and enjoyed the luxury of iced water. ${ }^{(41)}$ Memoirs of Sinai visitors were worldwide invitations to visit Sinai and enjoy the sun, which can be found in the Nile Valley, but the fresh air, according to Buxtons, was inclusive in Sinai. ${ }^{(42)}$

Even the religious visit to St. Catherine Convent included environmental and leisure sides, such as the climbing of the Mount of Sinai. This was fundamental part of pilgrimage to St. Catherin for both Christians and Saracens. The worshippers who used to ascend Sinai Mountain calculated the ascending steps at fifty thousands, a non-stop journey that tookabout two hours. $^{(43)}$

With the beginning of the $20^{\text {th }}$ century, tourist concepts had differed and foreign visitors to Sinai outnumbered the Egyptians. Because of its remarkable nature and healthy atmosphere, visits to Tor were recommended in spring (February-May) and winter (October to November). ${ }^{(44)}$

During the first half of the $19^{\text {th }}$ century, Ayoun Mousa was seen by Sinai visitors as an island in the desert. It represented for some Europeans Richmond of Suez. For travellers, "it presents a cheering sight to the eye fatigued by the long waste waterless from Suez to it". ${ }^{(45)}$ It was mainly used by the Egyptians for picnic. ${ }^{(46)}$ Burckhardt described the visit of Muhammed Ali's wives for this spot. ${ }^{(47)}$ For the elite and foreign visitors, Ayoun Mousa was an environmental attractions, but for the people of Sinai people it was principally used for remedies, especially for the extra doses of Manna. ${ }^{(48)}$ Foreign visitors did not use Ayoun Mousa for treatment, mostly because Europe was rich in therapeutic spots, with specific known treatments. ${ }^{(49)}$ As a resort and water source, always described as brackish water, Ayoun Mousa was more known for Sinai visitors. It was a group of wells ranged between 10 and 20 wells, which were surrounded by gardens. The group was private property of the Greek Consul, who did not pay any taxes, perhaps because it was difficult to keep it planted. ${ }^{(50)}$ Ayoun Mousa continued to be an important rest-house in the way of Sinai visitors. It kept its description as the desert oases in the 1930s, but with less importance probably because other rest-houses were built on the road from Cairo to Suez and to Sinai, such as Cook's at the $51^{\text {st }}$ kilometre from Cairo to Suez. ${ }^{(51)}$ 


\section{Collecting the Manna}

The manna (Arabic: Mann) is still rarely found in Sinai desert. In the middle of the $19^{\text {th }}$ century, it was produced every 5 or 6 years, but the quantity was in diminishing scale. It was collected as shining drops on the twigs and branches of the Turfa. It looks like gum and of sweetish taste and melts by the sun heat or fire. It is sold in Cairo by the druggists. Sinai was important destination for collecting the Manna by travellers. ${ }^{(52)}$ Definitely in Wadi Shikh, monks of St. Catherine Convent used to offer it to their visitors. ${ }^{(53)}$

\section{Hunting Tourism in Sinai}

Hunting has always been an important and prestigious aspect in Sinai; it was practiced by Sinai visitors. Rich wildlife in Sinai encouraged this kind of tourist activity. Sinai people have benefitted from organizing such hunting trips, a few also worked in arranging a day-trip for the Convent visitors. ${ }^{(54)}$

During the $18^{\text {th }}$ century, Sinai was still full of antelopes and Oryx. With the manufacture of weapons in Egypt, such animals were extinct in the $20^{\text {th }}$ century and nearly disappeared from Sinai. Burckhardt recounted the existence of ostriches in Sinai, and he justified their presence as coming from the east, the "Bedouins did not try to hunt them". (55)

During the $19^{\text {th }}$ century, the spotted hyena, the ibex, the gazelle, the coney, and a few other animals, had dwelt in Sinai mountains. This made it difficult to hunt them without a rifle. Species of partridge, sandgrouse, quail, duck and water fowls are occasionally found in Sinai. ${ }^{(56)}$ In 1892-93, Hannah Buxtons visited Sinai to hunt ibex and rams and enjoyed the nature of Sinai. Female hunter was unusually observed in Sinai, and Buxton was such a rare example and she described every detail related to her hunting experience in Sinai. The family anecdotes about her hunting experience were published in many books. ${ }^{(57)}$

Also, the famous hunter Robert Hayne was attracted by Sinai a few years before the WWI, where he hunted a leopard while chasing an ibex. ${ }^{(58)}$ Hayne was the only hunter recorded to shot a leopard in Sinai. Russell was another fan of ibex-hunting. Although he recommended the southern part of the Eastern Desert, he never missed hunting ibex in Sinai. He advised ibex lovers to use camels in their adventures to enjoy more. ${ }^{(09)}$ Jarvis, the British governor of Sinai, escorted hunting parties whose journeys were well organized by the British authorities. A subspecies of leopard in Sinai, F.P. Jarvis, ${ }^{(60)}$ was named after C.S. Jarvis (Fig.3). ${ }^{(61)}$

Water, guides, and trackers were the three prime necessities for hunting. ${ }^{(62)}$ Bedouin guides went a month beforehand to explore the hunting zone and decided the hunting plan. Any desert Bedouin could track more or less, but 
probably the best was the Besharian tribe. ${ }^{(63)}$ The governmental interest in Sinai game hunting could be touched in the "Shikaris", who were chosen from Sinautics and employed as guards for hunting in the mountains; an application should be submitted 15 days in advance. ${ }^{(64)}$

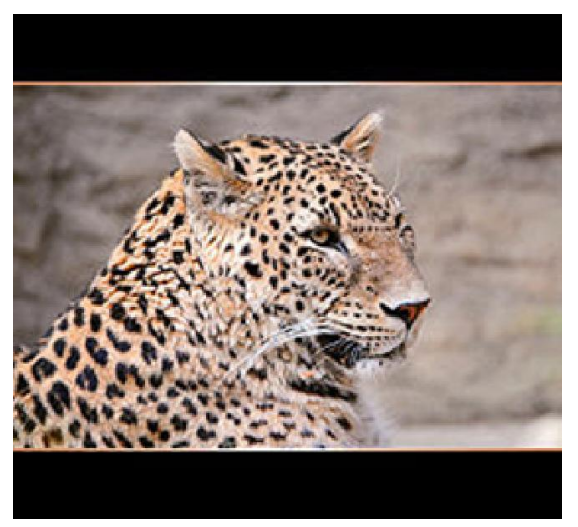

Fig. (3) Sinai leopard (known as Panthera Pardus Jarvisi)

Source $:$ https://www.google.com.eg/search?client=opera\&hs=jS\&dcr=0\&biw=1270\&bih=6 $09 \&$ tbm $=$ isch \&sa $=1 \& q=$ Sinai + leopard + Panthera + Pardus + Jarvisi\&oq=Sinai + leopard + Panth era+Pardus+Jarvisi\&gs_l=psy-ab.12...48255.49952.0.51602.2.2.0.0.0.0.220.425.2-

2.2.0...0...1.1.64.psy-ab..0.0.0...0.f8fVTVtguSU\#imgrc $=$ cmLLbHA48pA6pM:)

Sinai was under the control of the Frontiers Districts Administration through a military governor, a British officer with headquarter at El Arish. The governor is responsible for the maintenance of public security and the administration of law and anti-contraband measures. ${ }^{(65)}$

Hunting Permission should be obtained by Sinai visitors. Buxtons, in 1890 s, obtained hunting permission from a governmental official, who often used to reject unknown tracks wanted by foreign hunters, but eventually he accepted and welcomed Buxton's request. Later on, the Frontiers Administration, War Office, Cairo, tackled the mission of extracting hunting permissions, which was a permission for carrying rifle and not for hunting game. It was definitely a different matter if the requester was familiar or well-known to the British authority. Farman argued that foreigners used to obtain hunting permission easily even for the prohibited sites. Sinai hunting game, in particular, continued to be under British control. Guidebooks rarely announce the procedures and steps to hunt through Sinai. Ex-hunters like Jarvis and Buxton wrote about their experiences. Jarvis used to tackle the guiding mission for chosen individuals. Later Royal Automobiles Club ${ }^{(66)}$ and, after 1936, the Royal Hunting Club were responsible for acquainting the shooters with hunting procedures and arrangements. Before 1936, the application of hunting licences and provision of camel transport should be 
submitted at the Headquarters, Frontiers Administration, Ministry of War, Cairo, or to the governor at el-Arish. ${ }^{(67)}$

\section{The Game Trophies}

Gazelles were more plentiful in Sinai than ibexes, simply because the former rely on water less than the latter. ${ }^{(68)}$ During the first half of the 20th century, Dorcas gazelle (Fig. 4) was still available in the eastern sandy parts of Sinai. (69)
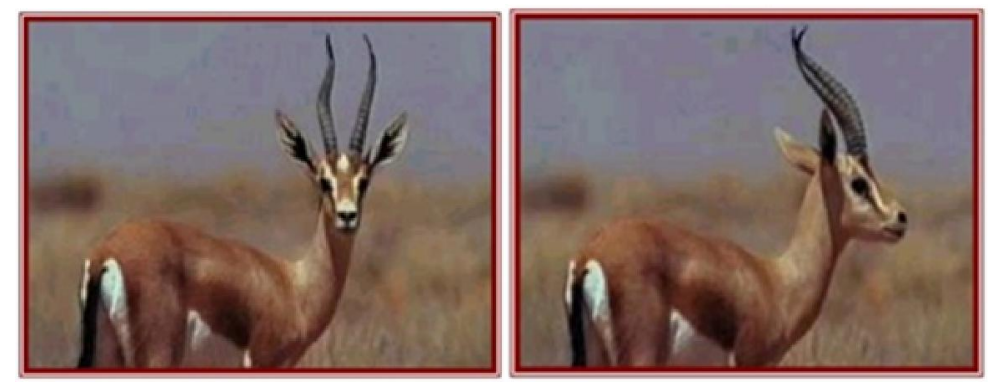

Fig. (4) Sinai Dorcas gazelle

(Source : Sinai Travel Guide,https://www.google.com.eg/search?q=Sinai+Dorcas+gazelle\&client= opera\&hs $=$ DBV \&dcr $=0 \&$ source $=1 \mathrm{nms} \& \mathrm{tbm}=\mathrm{isch} \& \mathrm{sa}=\mathrm{X} \& \mathrm{ved}=0$ ahUKEwiMh-

vQguPWAhXpBcAKHWxJC0sQ_AUICigB\&biw=1270\&bih=609\#imgrc=h0SdXhb3wnfPmM:)

The leopards also existed in the southern mountains of Sinai with reported victims of human and other animals. The white colour with black spots of the Sinai leopard distinguishes it from Indian and Sudanic species; it is too difficult to be haunted.$^{(70)}$ Leopards, foxes, and tigers are also frequent in Sinai. ${ }^{(71)}$ The Egyptian gazelle and hyena are similarly chased and hunted in Sinai. Examples of these hunted animals can be seen at the Royal Hunting Museum in the Manial Palace (Figs. 5-6).

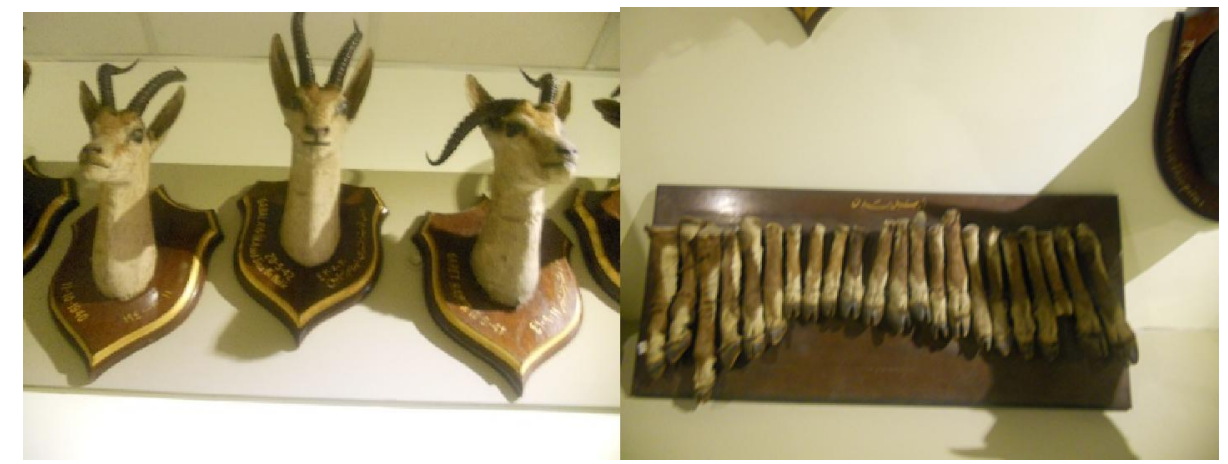

Fig. (5) Staffed Ibex heads from Sinai at the Royal Hunting Museum, Manial Palace.

Fig. (6) Preserved Ibex legs from Sinai at the Royal Hunting Museum, Manial Palace. 
Hunting birds in Sinai was practised by both tourists and dwellers. During $19^{\text {th }}$ century, Holland described Wadi Gharandel (as beds of bulrushes and reeds filled with wild ducks and many other kinds of smaller birds, because of the fresh water running in the spot. ${ }^{(72)}$ During the first half of the $20^{\text {th }}$ century, large numbers of many kinds of birds were under the custody of Bedouin policemen at Wadi Gedeirat. ${ }^{(73)}$ Hunting birds in Sinai was wellknown and well-organized with definite invited personalities, who were normally informed by phone. There was a blacklist of hunters, who should never attend hunting events in Sinai, because they misused their hunting permissions in previous parties. The lucky invited personalities were chosen by the British authority in Egypt. Many English keepers might go as far as to suggest to their masters the individuals who should be invited to shoot, but those keepers could not omit or black-ball their masters' guests. Hunting sandgrouse and quail was not common in Sinai. These birds were extensively collected by Sinai dwellers and were exported to Europe. ${ }^{(74)}$ El-Arish used to be an important station for migrant birds, where ornithologists travelled and settled in Sinai to study these immigrant birds.

Dogs were heavily used in hunting at Sinai, and they were exported to Europe during the $19^{\text {th }}$ century because of their outstanding capabilities. In Sinai, the "Durri" dog was used for hunting the ibex by chasing and biting its leg until the shooter arrives and catches the ibex by hand or by shooting it. ${ }^{\left({ }^{\circ}\right)}$ The Saluki dog was a permanent company for Jarvis and hunters' parties in Sinai game (Fig.7). ${ }^{(76)}$

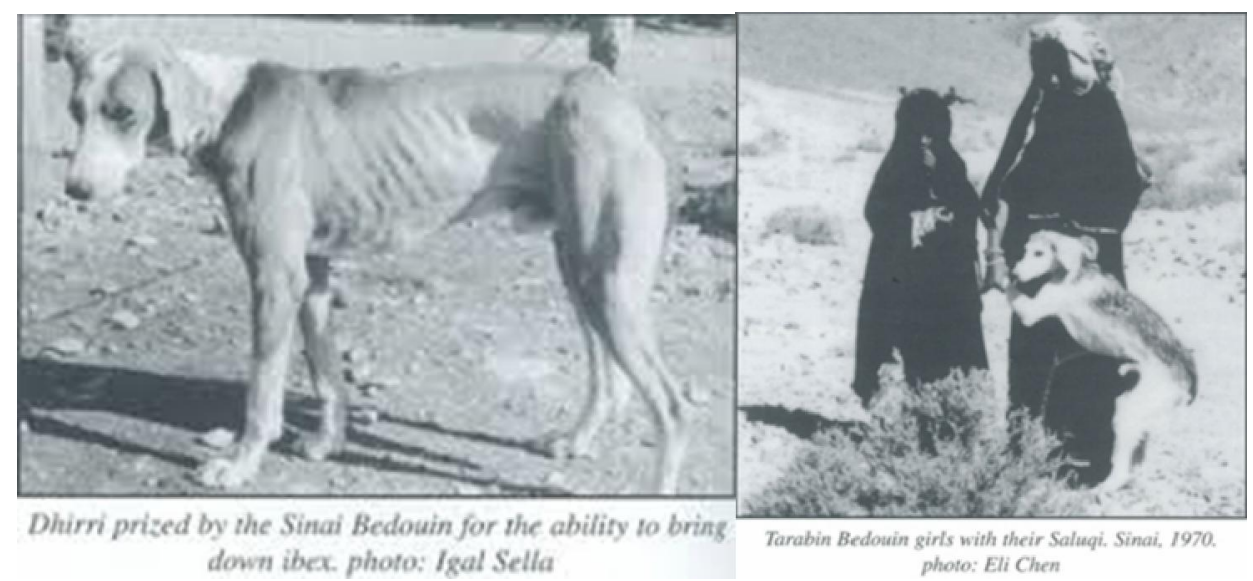

Fig. (7) Dhirri and Saluki dogs used in hunting in Sinai, (Source: Goodman,Gail Travels: Israel, Sinai, Palestine Part 2) (http://www.midbarsalukis.com/pilgrimage/travelspart2.html).

Until the end of King Fouad's reign in 1936, the fishing base of Sinaiw had not been recognized. The right of fowling, like that of fishing, was farmed 
out and shooting from a boat was prohibited, but permission to hunt could generally be obtained by foreigners. The British officers, according to Jarvis, enjoyed fishing sharks in the Aqaba Bay. ${ }^{(77)}$

The different and numerous procedures applied to protect wild life in Sinai were certainly useful, yet they could not prevent extinction of Sinaitic fauna rarities. Khedive Abbas Helmi II led national campaign to preserve Egypt's fauna, especially immigrant birds during the first decade of the $20^{\text {th }}$ century. ${ }^{(78)}$ Jarvis, the Sinai military governor, imposed strict regulations to prevent and control hunting in Sinai, for him settlers' hunting was responsible for many extinction cases of Sinai rare animals. According to Jarvis, uncontrolled hunting in Sinai had diminished in the 1930s, because the Sinai people were deprived of weapons after WWI, which prevented them from hunting. ${ }^{(79)}$ As shooting and hunting of Dorcas gazelles has been prohibited in Sinai in the 1920s, the Dorcas gazelles gradually increased to some extent. ${ }^{(80)}$ For the ibex, severe penalties were imposed to prevent sale of ibex meat. Ghaffirs or watchmen were appointed on various mountains to prevent ibex hunting.

Thanks to $6^{\text {th }}$ of May decision in 1930 taken by Jarvis that the fauna in Sinai was preserved at least for five consecutive years. Jarvis prevented the trade on ibex meat, and expropriated rifles and other weapons of Sinai settlers. ${ }^{\left({ }^{\prime}\right)}$ Jarvis worked hard in Sinai to regulate the quail hunting and preserve it on the peninsula, and, according to him, the regulations were strictly enforced. ${ }^{(82)}$ These regulations were not popular with the Arab, who firmly believes that Allah brings the quail up out of the sea for his own special benefit. ${ }^{(83)}$, Russell bore the Bedouins the responsibility for ibex extinction, hence he persuaded the Egyptian government to form a special gamepreservation patrol to check the Bedouins hunting activities. ${ }^{(84)}$

Hunting game in Sinai was a VIP affair that was not mentioned in guidebooks. Few details of this category of tourism in Sinai are available, mostly because the regulations prevented hunting in Sinai to preserve the fauna. However, the law's enforcement cannot be guaranteed once it is issued.

The Royal Automobile Club d'Égypte was responsible for the maintenance of the tracks and routes of Sinai in addition to the publication of guidebooks. The Royal Hunting Club later adopted the organization of hunting in Sinai and other parts of Egypt, including the Western Desert and the Fayoum. The club issued a map of the Nile Valley, in which the Egyptian kingdom was split into 12 sections. It had conducted an individual study of each section in terms of the facilities, roads, weather, wealth, the customs of the population, and the kinds of birds and animals available. ${ }^{(85)}$ later on, the club also issued 
a more specific map highlighting the hunting places (Fig.8) and the weapons allowed in the areas.

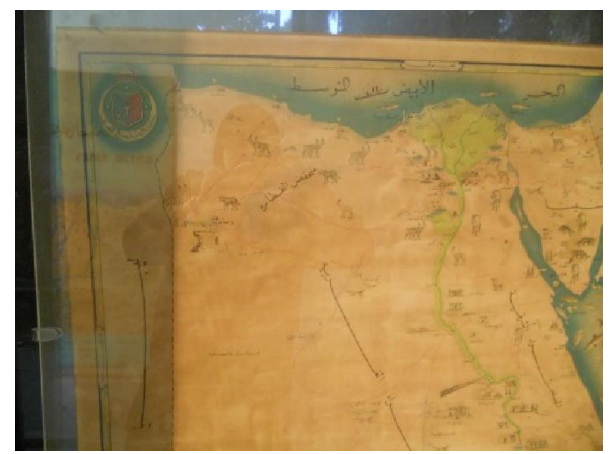

Fig. (8) Map of hunting spots in Egypt by the Royal Hunting Club.

(Royal Hunting Museum, Manial Palace)

Important spots for hunting in Sinai were well-known and sometimes shooting parties chose another unbeaten tracks for extra suspense. The unbeaten tracks included Gebel Tarbush, the exploration of which normally took about three days. Gebel Serbal was another important an ibex-shooting arena. Neither o car nor camel was used in ibex-shooting in these mountains. Yet ibex arenas such as Gebel Gourna and Habashi were reached by cars. ${ }^{(86)}$ The absence of Egyptian elites from the hunters' list in Sinai can probably be justified by the fact that Sinai hunting game was under British control until 1936.

\section{Factors contributed to increasing the Number of Sinai visitors:}

There are many factors that effectively contributed to increasing the number of Sinai visitors. Sinai enjoys an important strategic location, making it an arena for historical moments such as WWI. The numbers of visitors to Sinai heavily increased after WWI. The development of steam railroads and ships in Europe made access to such remote spots as Sinai more possible. According to Thomas Cook's in 1876, the development of modern travel made the visit of the Mount Sinai peaks no longer mysterious or shadowy as it once was.

Guidebooks that were issued about Egypt and included Sinai as part of its program were highly important, because they let the world know more about Sinai and think about visiting it. The earliest modern guidebook was issued in the 1830s, it was authored by the French J. J. Rifaud, ${ }^{(87)}$ who designed optional trips to the Red Sea and Sinai. Another French publication was that of Joanne, which included Sinai in $1861 .^{(88)}$ Equally, the guidebooks of Wilkinson and Murray included Sinai with mention of the required visit arrangements, ${ }^{(89)}$ though they primarily focused on its archaeological 
remains. Cook later added the charming hints of Sinai nature, which can be enjoyed during pilgrim or following Israel and Moses incidents in Sinai and attempting to define its exact locations. ${ }^{(90)}$ The first Baedeker's guide of Egypt was issued in German in 1877 and it was followed by an English edition in 1878. Baedeker, Murray, and Cook issued 16 editions on Palestine, in which Sinai was mentioned in brief. They also issued 25 editions on Egypt, including Sinai, though they mostly focus on the religious destinations of Sinai. The British Occupation controlled almost all affairs in Sinai, including tourism arrangements. During that time, guidebooks began to publish cautious statements, warning travellers from being in Sinai without consulting British security officials. ${ }^{(91)}$ After Taba 1906 incident and WWI, Sinai was governed by a British military governor, beginning with Parker and then Jarvis, who offered their experiences in their books to those who wanted to visit Sinai. The Egyptian Intelligence and Frontiers Administrations officers wrote guidebooks on Sinai, in which they neglected the description of the internal affairs of Sinai, especially hunting activities. Some opinions suggest that the hospitality of the Bedouins was also decisive in attracting more visitors to Sinai. Sometimes, they willingly share with the traveller their last few scraps of bread. ${ }^{(92)}$

Important visitors shed more light on Sinai as a unique tourist destination that worthy to be visited. Prince M. S. Vorontsov, for example, visited Sinai as part of an inclusive program to Egypt. ${ }^{(* 93)}$ Unsurprisingly, the focus of his journey and detailed description is Sinai. ${ }^{(94)}$ The Prince of Wales was also a prominent royal visitor to Sinai in the $19^{\text {th }}$ century, though it was only part of his visit program to Jerusalem. ${ }^{(95)}$ This journey throws light on Sinai and his trip became a model, which continued to be imitated by world dignitaries. ${ }^{(96)}$ A year later,the Crown Prince of Belgium visit Sinai, where his trip was commemorated in a book, which included full description of the visit of the Belgium prince. ${ }^{(97)}$ The book had an influential effect on the promotion of Egypt in general and Sinai in particular as important tourist attractions. ${ }^{(98)} \mathrm{Le}$ Comte De Pardieu similarly visited Egypt as part of a long journey, which was described in detail and published in $1851 .{ }^{(99)}$ Said Pasha exerted every effort in welcoming this important visitor, for he prepared 138 camels and 150 servants for the Comte journey through Sinai.

The inauguration arrangements of the Suez Canal included a tourist program for the guests. Although the program did not include Sinai, certain VIPs like Paul Lenoir, Bonat, and Leon Gerome requested to visit Sinai. ${ }^{(101)}$ King of Hawaii had also been to Sinai in 1882, yet he mainly visited St. Catherine Convent. ${ }^{(102)}$ He praised Sinai's environment and religious monuments. ${ }^{(103)}$

During the $20^{\text {th }}$ century, there were facilities for travellers to Sinai, where they could communicate with the world from Sinai, thanks to the military 
and police presence. ${ }^{(104)}$ The paved tracks in the desert of Sinai and the construction of governmental rest-houses, which cost an individual traveller30 PT, compensated the absence of hotels in Sinai. The private sector was unable to build hotels in Sinai, mainly for security reasons and traffic deficiencies. ${ }^{(105)}$ However, the Royal Automobile Club d'Egypte regularly added posts to Sinai tracks and paved roads. ${ }^{(106)}$

\section{Conclusion}

It was difficult to practice secular types of tourism in Sinai in isolation from religious attractions. Sinai visitors paid much more attention to visit religious sites of Sinai, which witnessed dramatic religious incidents mentioned in Jewish, Christian, and Muslim holy books. Such historic incidents included the Hebrews crossing the Red Sea into the Promised Land and the speech of Moses to God and the reception of the Ten Commandments. The enjoyment with the picturesque nature of Sinai has soon been enlisted and accompanied the religious visits since the Middle Ages.

Environmental tourism in Sinai depended mainly on rare natural characteristics and picturesque scenes. Even the early visits to religious sites of Sinai included environmental attractions, but they were kept untold as a kind of respect for the religious purpose of the visit. Undoubtedly, it was more respectful and prestigious to state that someone has been in Sinai for pilgrimage. ${ }^{(107)}$ The visit to Sinai continued to equally combine religious sites and natural destinations. All kinds of tourism in Sinai were strongly dependant on the security state of the peninsula. The authority of Egypt's ruler influenced Sinai's security. The more powerful the ruler was, the more security measures for travellers through Sinai were taken.

Before 1936, only governmental, namely military, facilities were secured for foreign recommended visitors, whose names were previously and nearly secretly listed. Hunting either in Sinai or other parts of Egypt used to be a privilege for VIPs because of the spread of the world preservative attitude for the flora and fauna.

Hunting, against the law, was opened for definite groups in Sinai, who were invited in season to practice their favourite hobby. The main sponsors of tourism in Sinai differed from 1805 to 1936. First Egypt's rulers were the main sponsors, then the British Occupation authorities took up the responsibility, together with the Frontiers Administration, the Royal Automobile Club, and the Royal Hunting Club, ach had its own distinctive role.

\section{References}


1) Saad El-Din, M. 1998. Sinai: The Site and the History: Essays, NYU Press, p. 10.

2) Moscrop, J. J.. 2000. Measuring Jerusalem: The Palestine Exploration Fund and British Interests in the Holy Land, A and C Black, p. 58.

3) Pilgrims who mainly visited the convent of St. Catherine for months, might also have visited other spots around the convent. Travellers also used to make short visits to the Convent as part of their journey through Sinai.

4) Manley, D. and Abdel-Hakim, S. 2009. Traveling Through Sinai: From the Fourth to the Twenty-First Century, AUC Press, Cairo, p. 35.

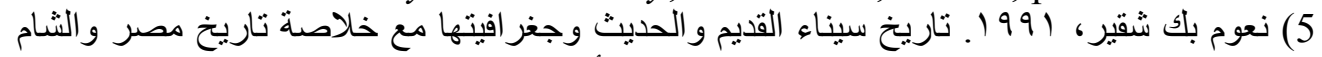

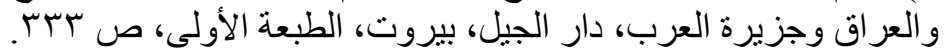

6 ) Farman, E. E. 1911. Egypt and its Betrayal: An Account of the Country during the Periods of Ismail and Tewfik Pashas, and of how England acquired a New Empire, The Grafton Press, New York.

7 ) Stanley, A. P. 1856. Sinai and Palestine, in Connection with their History,

A. C. Armstrong and Son, New York.

8 ) Browne, W. G. Travels in Africa, Egypt and Syria from the Year 1792 to 1798, London 1799.

9) The Spectator, 3 December 1921, p. 27.

10) Eckenstein, L. 1921. A History of Sinai, London,.

11) Hassan, F. 1999-2000. A Betrayal of History Al-Ahram Weekly.

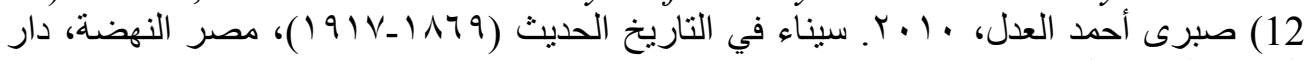

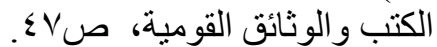

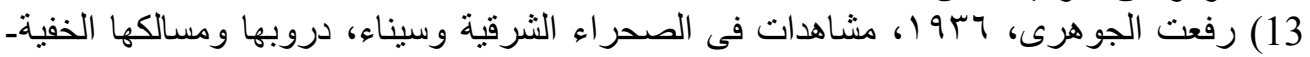

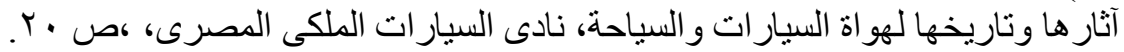

14) Murray, 1880. A Handbook for Travellers in Lower and Upper Egypt II, Sixth edition, London, p. 330.

15) Abdel-Hakim, S. 2009. Traveling Through Sinai: From the Fourth to the Twenty-First Century, AUC Press, Cairo, p. 43.

$$
\text { 16) رفعت الجو هرى، مرجع سابق، صاب آ. }
$$

17) Jarvis, C. S. 1932. Yesterday and to-day in Sinai, Houghton Mifflin Company, Boston pp. 295-311.

18) Jarvis $19 r \mathrm{r}$, p. 70.

19) Brian, P. S. 2009. The Desert Hound and the English Travelers: Who Brought it to the West, McFarland, p. 200.

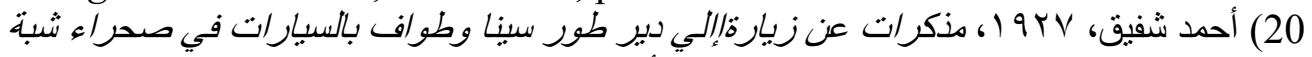

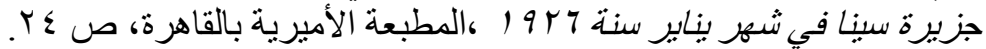

21) Jarvis 1932, p. 291. 


$$
\text { 22) نفسه ، صن الجو هرى، مرجع سابق، ص 11 11. }
$$

24 ) Wolff, A. 2003. How many miles to Babylon?:Travels and Adventures to Egypt and Beyond, 1300 to 1640, Liverpool University Press, p. 197.

25) Abdel-Hakim 2009, p. 34.

26) Murray 1880, p. 330.

27) Petrie, W. M. F. 2013. Researches in Sinai, Cambridge University Press, A New Edition, p. 4.

28) Murray 1880, p. 330.

29) Thomas Cook Ltd, 1907. Cook's Handbook for Palestine and Syria, Thos. Cook \& Son, pp. 365-66.

30) Swiss-born Dominican from Ulm, whose pilgrimages to Jerusalem was in 1480 and 1483 and followed with visits to the holy sites of Sinai. $\mathrm{He}$ described his visits in many books.

31) Prescott, H. F. M. 1958. Once in Sinai: the Further Pilgrimage of Friar Felix Fabri, New York, p. 107.

32) Jebel Musa, or "Mount Moses", is revered by most Christians and Muslims as Mount Sinai. For an important study on Mount Sinai, see Hobbs, J. J. 2014. Mount Sinai, University of Texas Press.

33) Willkinson, F. R. S. 1847. Handbook for Travellers in Egypt, London, p. 220.

34) Grandson and successor of the great reformist Muhammad Ali Pasha.

35) Tour Egypt., an online source available

at (http://www.touregypt.net/walkingtours/jebelabbaspasha.htm\#ixzz2uhcS5f F2)

36) Mohamed, H. 2014. "Safari Tourism in Egypt under the Reign of Mohamed Ali Family (1805-1952), Proceedings of the Conference of Environmental Studies, South Valley Univ.

37) Bonar, H. 1857. The Desert of Sinai: Notes of a Spring-journey from Cairo to Beersheba, R. Carter \& Brothers, New York, pp. 199-200.

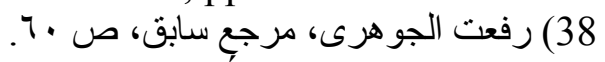

39) De Comte, P. Ch. 1851. Excursion en Orient : l'Égypte, le mont Sinaï, l'Arabie, la Palestine, la Syrie, le Lyban Paris, p. 201-204.

40) Cook's Tourists' Handbook for Egypt, the Nile, and the Desert, 1876, p. 248.

41) Bolton, H. C. 1890. 'Four Weeks in the Wilderness of Sinai, with Notes on Egypt', JAGSNW 22, pp. 575-98. 
42 ) Buxton, E., Buxton, C. E., and Maud, H. 1895. On Either Side of the Red Sea, Edward Stanford, London, p. 7.

43) Henniker, F. 1823. Notes during a Visit to Egypt, Nubia, the Oasis, Mount Sinaï, and Jerusalem, p. 229.

$$
\text { 44) نعوم شقير ، مرجع سابق ، ص . ' . . }
$$

45) Beamont, W. J. 1860. Cairo to Sinai and Sinai to Cairo: Being an Account of a Journey in the Desert of Arabia, November and December, Deighton, Bell \& Company, p. 26.

46) Stanley, A. P. 1863. Sinai and Palestine: In Connection with Their History, W. J. Widdleton, p. 66.

47) Burckhardt, J. L. 1822. Travels in Syria and the Holy Land, John Murray, p. 460.

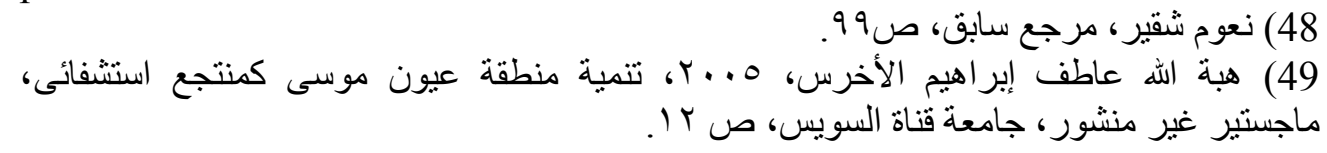

50) Beamont 1860, p. 26.

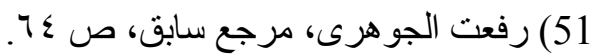

52) Wilkinson, J. G. 1858. A Handbook for Travelers in Egypt, Jogn Murray, p. 215.

53) Murray, G. W. 1953. 'The Land of Sinai', The Geographical Journal 119/No. 2, pp. 140-53.

54) Rabinowitz, D. 1985. 'Themes in the Economy of the Bedouin of South Sinai in the Nineteenth and Twentieth Centuries', IJMES 17/No. 2, pp. 21128.

55) Burckhardt 1822, p. 461.

56) Cook's Tourists' Handbook for Egypt 1876, p. 248.

57) E.g. Buxton, E. N. 1895. Stony Sinai. An account of a Visit, Nineteenth Century, First Edition.

58) Arab Spring and the Bedouins I: History and Politics.

59) Russell, Thomas 1923. Egyptian Service, $1^{\text {st }}$ ed. London, p. 104.

60) The Sinai leopard (Panthera Pardus Jarvisi) is a critically endangered leopard species native to the Sinai peninsula in Egypt and since the late 1990 's, leopards were no longer recorded in Egypt anymore. It is one of the three subspecies of the African leopard along with the Barbary and Zanzibar. There were other leopard species in Egypt, including the Arabian, African, 
and Barbary. (Abe's Animals http://abesanimals.blogspot.com.eg/2016/02/sinai-leopard.html).

61) Qumsiyeh, M. B. 1996. Mammals of the Holy Land, Texas Tech University Press, p. 168.

62) Trackers were can move through the desert even by night, knew the details of the desert tracks and follow the steps of preys easily.

63) Russell, p. 105.

64) Jarvis 1932, p. 311.

65) A Military Report on Egypt, General Staff, The War Office, May 1938, p. 190.

66) For more information on Royal Automobiles Club d'Egypte, see Annuaire et Guide Touristique 1934-1935/du Royal Automobile Club d'Egypte, Cairo, 1934.

67) Jarvis 1932, p. 312.

68) Greenwood, N. 2010. The Sinai: A Physical Geography, University of Texas Press, p. 129.

69) Jarvis 1932, p. 201.

70) Jarvis 1932, p. 213.

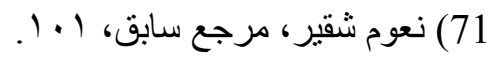

72) Holland, F. W. 1868. 'On the peninsula of Sinai', JRGSL 38, pp. 237-41.

73) This valley was the birds' preferred resident place, because of its plentiful supply of water and corn. Hunting season was September and October.

74) A Military Report on Egypt, General Staff, The War Office, May, 1938, p. 197.

76 ) Brian, P. S. 2009, p. 202.

$$
\text { 75) نعوم شقير ، مرجع سابق، ص ... }
$$

77) Farman 1908, p. 117.

78) Mohamed 2016.

79) Jarvis 1932, p. 202.

80) Jarvis 1932, p. 206.

81) Manlius, N. 2001. 'Biogéographie et Ecologie historique du bouquetin de Nubie en Egypte Belgian', Journal of Zoology 131.

82 ) Jarvis 1932, p. 262.

83) The Egyptian regulations decree that no net is to be erected within 500 yards of the shore in Sinai and 1000 yards of the shore in the Western Desert; that every kilometre there is to be a gap of 100 yards in which no nets are erected and netting is absolutely prohibited on a 25 -mile stretch immediately to the east of Port Said (Mohamed 2016). 
84) Russell, p. 103.

85) Rizk, Y. L. 2007. 'Join the Club', Al-Ahram: A Diwan of Contemporary Life (663), 8-14 February 2007, Issue No. 831.

86) Jarvis 1932, p. 311.

87) Jean-Jacques, R. (1786-1852) is the author of Tableau de L'Egypte, de La Nubie et des Lieux Circonvoisins.

88) Reid, D. M. 2002. Whose Pharaohs? Archaeology, Museums, and Egyptian National Identity from Napoleon to World War I, UC Press, Cairo, p. 71-72.

89) Sir John Gardner Wilkinson (5 October 1797-29 October 1875) was an English traveller, writer, and pioneer Egyptologist of the 19th century. He is often referred to as "the Father of British Egyptology".

90) Thomas Cook (22 November 1808-18 July 1892) was an English businessman. He is best known for founding the travel agency Thomas Cook \& Son.

91) Cook's Handbook 1907, p. 364.

92) Jarvis 1932, p. 33.

93) Prince Mikhail Semyonovich Vorontsov was a Russian prince and fieldmarshal, he is renowned for his success in the Napoleonic wars and his participation in the Caucasian War from 1844 to 1853.

94) Kalfatovic, M. R. 1992. Nile Notes of a Howadji: A Bibliography of Travelers' Tales from Egypt, from the Earliest Time to 1918, Scarecrow Press, 1992, p. 143.

95) Moscrop, J. J. 2000. Measuring Jerusalem: The Palestine Exploration Fund and British Interests in the Holy Land, A \& C Black, 2000, p. 47-48.

96) Stanley, A. P. 1859. Sermons Preached Before His Royal Highness the Prince of Wales: During His Tour in the East in the Spring of 1862 with Notices of Some of the Localities Visited, John Murray.

97) Relations d'apres les notes tenues pendant le voyage de S.A.R msg. Le duc de Brabant entrepris dans ces contrees en 1836, Liege, 1865.

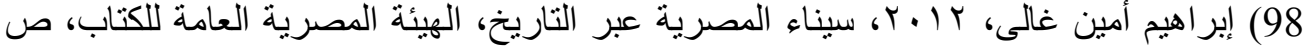

99) Pardieu 1851.

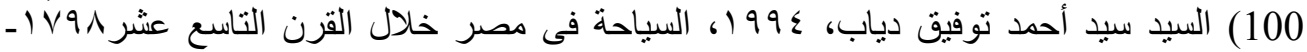

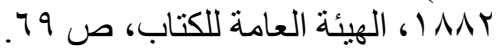

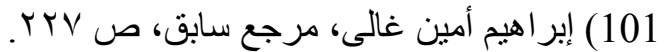

102) Hawiian King Kalākaua asked if the mountain was sacred to Christianity, why was it in the hands of the Muslim Ottoman Turks (who 318 
controlled much of the Middle East)? A British officer replied that Ottoman rule was not challenged because trade with Turkey was more important than religious sentiment. (A. Hawiian History, Nov. 3, 2010, Iā 'Oe e ka Lā: Around the World with King Kalākaua Part 1). This source is available online at(http://hawaiianhistorian.blogspot.com.eg/2010/11/ia-oe-e-ka-laaround-world-with-king.html).

103) Armstrong, W. N. 2013. Around the World with a King, Tuttle Publishing, p. 215.

104) Nakhl, Kuntilla, Themed, and Magdaba by paying the police orderly for a telegram and getting him to telephone the message to El-Arish from where the message will be telegraphed. The Language difficulty can be overcome by the traveler using the telephone himself and asking for an Englishspeaking clerk to answer him. At El Arish, Abu Zeneima, and Tor by ordinary telegram from the telegraph office. At El Arish, Akaba, Auja, Beersheba, and Asluj wireless stations exist, and these places communicate with each other and with Cairo and Jerusalem.

105) Jarvis 1932, p. 294.

\section{Bibliography}

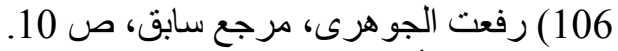

$$
\begin{aligned}
& \text { 107) إبر اهيم أمين غالى، سيناء عبر التاريخ، ص م • ب. }
\end{aligned}
$$

\section{Published Documents}

Military Report on Egypt, General Staff, The War Office, May, 1938.

\section{References}

Armstrong, W. N. 2013. Around the World with a King, Tuttle Publishing.

Beamont, W. J. 1860. Cairo to Sinai and Sinai to Cairo; Being an Account of a Journey in the Desert of Arabia, November and December, Deighton, Bell \& Company.

Bolton, H. C. 1890. 'Four Weeks in the Wilderness of Sinai, with Notes on Egypt', J AGS NY 22.

Bonar, H. ....., The desert of Sinai: Notes of a Spring-journey from Cairo to Beersheba.

Brian, P. S. 2009. The Desert Hound and the English Travelers Who Brought it to the West, McFarland.

Burckhardt, J. L. 1822. Travels in Syria and the Holy Land, John Murray.

Buxton, E., Buxton, C. E. And Maud, H. 1895. On Either Side of the Red Sea, Edward Stanford, London.

Cook's Tourists' Handbook for Egypt, the Nile, and the Desert, 1876.

Eckenstein, L. 1921. A history of Sinai, S.P.C.K., London. 
Farman, E. E. 1908. Egypt and its Betrayal: An Account of the Country during the Periods of Ismail and Tewfik Pashas, and of how England acquired a New Empire, The Grafton Press, New York.

Henniker, F. 1823. Notes During a Visit to Egypt, Nubia, The Oasis, Mount Sinaï, and Jerusalem, John Murray.

Jarvis, C. S. 1932. Yesterday and to-day in Sinai, Boston Houghton Mifflin Company.

Kalfatovic, M. R. 1992. Nile Notes of a Howadji: A Bibliography of Travelers' Tales from Egypt, from the Earliest Time to 1918, Scarecrow Press.

Manley, D. and Abdel-Hakim, S. 2009. Traveling Through Sinai: From the Fourth to the Twenty-First Century, AUC Press, Cairo, 2009.

Mohamed, H. 2014. 'Safari Tourism in Egypt under the Reign of Mohamed Ali family (1805-1952)', Proceedings of the Conference of Environmental Studies, South Valley Univ.

Saad El-Din, M. 1998. Sinai: The Site \& the History: Essays, NYU Press.

Moscrop, J. J. 200. Measuring Jerusalem: The Palestine Exploration Fund and British Interests in the Holy Land, A \& C Black.

Murray, J. 1880. A Handbook for Travellers in Lower and Upper Egypt II, $6^{\text {th }}$ edition, London.

Murray, G. W. 1953. 'The Land of Sinai', The Geographical Journal. 119/ No. 2.

Greenwood, N. 2010. The Sinai: A Physical Geography, University of Texas Press.

De Comte, P. Ch. 1851. Excursion en Orient: l'Égypte, le mont Sinaï, l'Arabie, la Palestine, la Syrie, le Lyban, Paris.

Petrie, W. M. F. 2013. Researches in Sinai, Cambridge University Press.

Prescott, H. F. M. 1958. Once in Sinai: the Further Pilgrimage of Friar Felix Fabri, New York. Qumsiyeh, M. B. 1996. Mammals of the Holy Land, Texas Tech University Press.

Reid, D. M. 2002. Whose Pharaohs? Archaeology, Museums, and Egyptian National Identity from Napoleon to World War I, AUC Press, Cairo, 2002 Relations d'apres les notes tenues pendant le voyage de S.A.R msg. Le duc de Brabant entrepris dans ces contrees en 1836, Liege, 1865.

Stanley, A. P. 1859. Sermons Preached Before His Royal Highness the Prince of Wales: During His Tour in the East in the Spring of 1862 with Notices of Some of the Localities Visited, J. Murray Stanley, A. P. 1863. Sinai and Palestine: in Connection with Their History, W. J. Widdleton, 1863. 
Stanley, A. P. 1856. Sinai and Palestine, in connection with their history, A. C. Armstrong and Son, New York.

Thomas Cook Ltd, 1907. Cook's Handbook for Palestine and Syria, Thos. Cook \& Son.

Wilkinson, J. G. 1858. A Handbookfor Travelers in Egypt, J. Murray.

Browne, W. G. 1799. Travels in Africa, Egypt and Syria, from the Year 1792 to 1798 , London.

Willkinson, F. R. S. 1847. Handbookfor Travellers in Egypt, London.

Wolff, A. 2003. How Many Miles to Babylon?: Travels and Adventures to Egypt and Beyond, 1300 to 1640, Liverpool University Press.

\section{Arabic References}

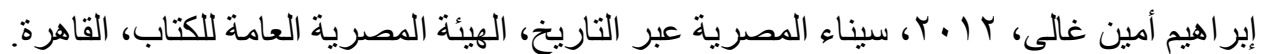

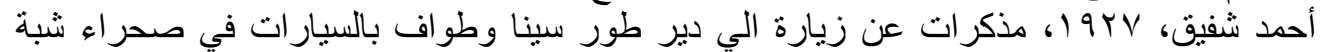

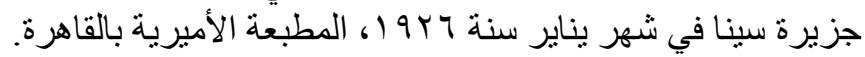

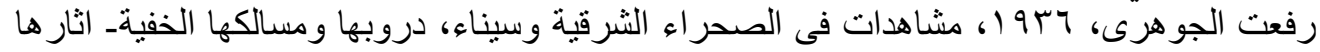

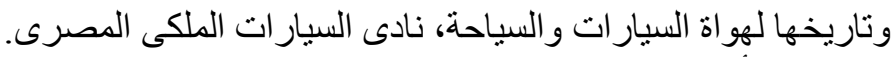

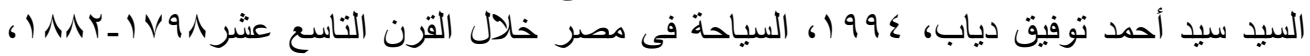

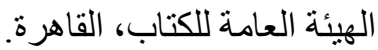

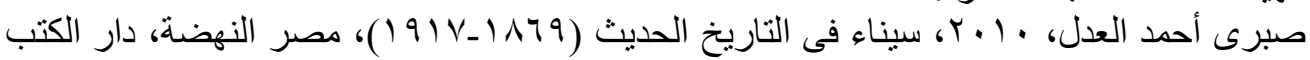
و الوثائق القومية، القاهرة.

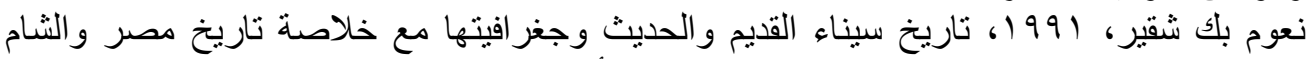
و العراق وجزيرة العرب، دار الجيل بيروت، الطبعة الطبعة الأولى.

\section{Periodicals}

Al Ahram Weekly 2000,2007

The Spectator 1921

Journal of Zoology 2001

International Journal of Middle East Studies 1985

The Journal of the Royal Geographical society of London 1868

\section{Websites}

Hawiian History, Nov. 3, 2010, Iā 'Oe e ka Lā: Around the World with King Kalākaua, Part 1

http://hawaiianhistorian.blogspot.com.eg/2010/11/ia-oe-e-ka-la-aroundworld-with-king.html.

Tour Egypt, http://www.touregypt.net/walkingtours/jebelabbaspasha.htm\#ixzz2uhcS5fF2) 
Abe's Animals http://abesanimals.blogspot.com.eg/2016/02/sinaileopard.html

\section{ملخص البحث بالعربية}

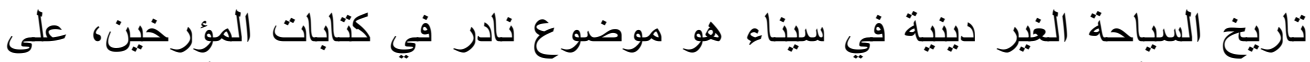

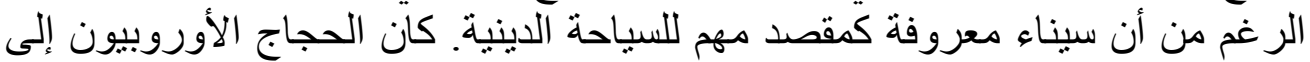

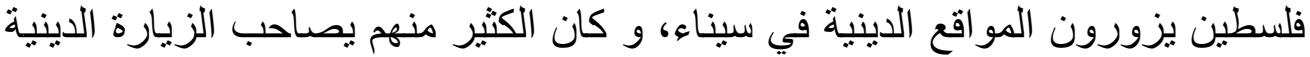

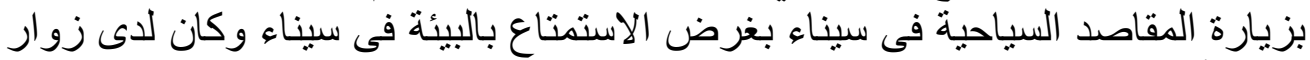

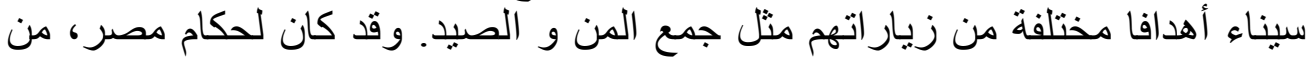

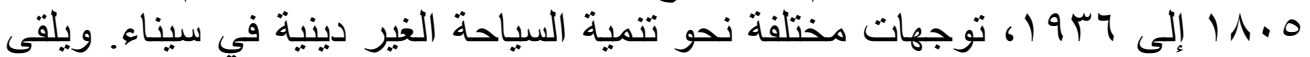

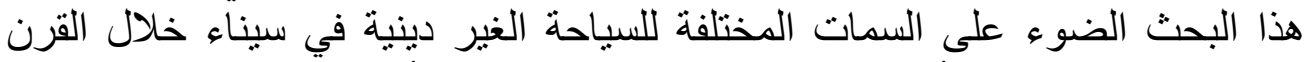

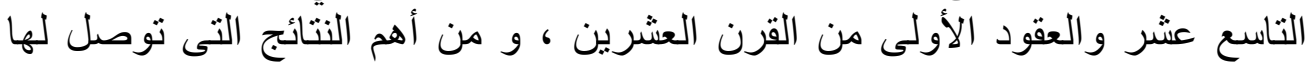

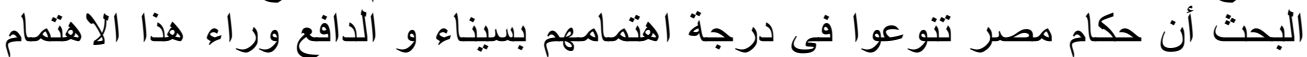

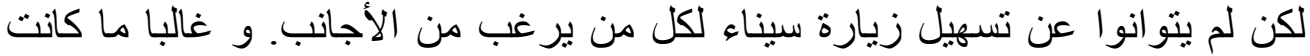

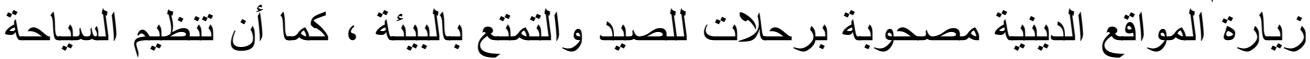

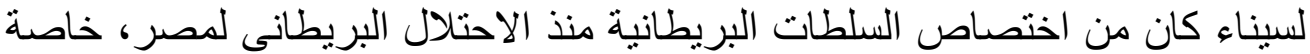

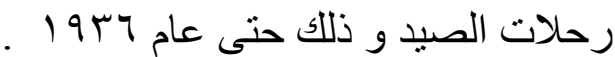
الكلمات الدالة : سيناء، عيون موسى ،الصئ والصيد، المن ، نوبيع، العريش، جبل طور سيناء،

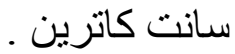

